\title{
Comparative analysis of rotifer community in two Rayahs of River Nile, Egypt
}

\author{
Gamal M. El-Shabrawy ${ }^{1}$, Faten A. El-Feqy ${ }^{2}$, Neveen H. Mahmoud ${ }^{2}$ \\ and Khadiga M.G. Gaber ${ }^{1}$ \\ 1- National Institute of Oceanograpgy \& Fisheries (NIOF) \\ 2- Faculty of Science - AlAzhar University
}

\begin{abstract}
The rotifer communities were determined in El-rayah El-Nasery and El-rayah ElTawfeky (Egypt) as small branches of River Nile by tracking seasonally variations in diversity and population density. It was found that the annual density of rotifers in El-Rayah El-Nasery (5442000 Ind. $/ \mathrm{m}^{3}$ ) was higher than that in El-Rayah El-Tawfeky $(3680000$ Ind. $/ \mathrm{m}^{3}$ ).The highest density of rotifer occurring in spring season but the lowest density occurring in winter season in the two rayahs. A total of 40 rotifer species were identified in the present study. The highest number of species and richness was observed in summer and the lowest number and richness was recorded in winter season. Of these species, Prolides sp, Keratella cochlearis, $k$. tropica, Brachionus calyciflorus, B. caudatus, Polyarthra vulgaris, Philodina roseola and Tricocerca pusilla were abundant.
\end{abstract}

Key words: Rotifer community, El-rayah El-Nasery and El-rayah El-Tawfeky, Nile river.

\section{INTRODUCTION}

Rotifers are a particularly significant group of the littoral and limnetic microinvertebrates (Wallace and Snell, 2010). Rotifers are jelly plankton (gelata) with no export endoskeleton and a water content of $92 \%-98 \%$ that are usually more or less transparent (Dumont, 2007). Rotifers contain about 2030 species worldwide (Segers, 2007).

The apparent dominance of rotifers in rivers may be due to their relatively short generation time compared to the larger crustacean zooplankton (Van Dijk and Van Zanten, 1995 \& Mola, 2011). In addition also its simple parthenogentic reproduction (Herzig, 1983) which in favorable conditions results in high production rates often manifested as very high population densities (Andrew and Fizsimons, 1992) and they are less vulnerable to fish predation (Brook and Dodson, 1965, Allan, 1976). Rotifers are also able to reproduce over a wide temperature range (Galkovskaja, 1987). The eutrophication affects the composition of zooplankton, shifting the dominance from large species (Copepoda) to smaller species (Rotifer) (El- Shabrawy, 2000; Emam, 2006; Mola, 2011).

Rotifers are highly nutritious food for the larvae of aquatic crustaceans and fish and have complex diversity and distributions in fresh water because many samples species are cosmopolitan (Segres, 2008). They are very good indicators of alterations in water quality because they respond quickly to environmental changes (Gannon and Stumberger, 1978).

Most of the studies conducted on the plankton of the River Nile were concerned with certain areas of the River (Aboul Ezz et al, 1996; Abd El-Mageed, 2001; Galal and Gaber, 2002; Bedair, 2006; Emam, 2006; Abo- Taleb, 2009; Elfeky and Khalifa, 2014). These studies have shown that Rotifer group contributed about $54 \%$ to the total number of zooplankton community.

No recent studies of the rotifer community in rayahs of River Nile have been conducted; therefore, this study was conducted to investigate the density of the rotifer community in two rayahs of River Nile (El-Rayah El-Tawfwky and El-Rayah El-Nasery) and the relationship between water parameters and rotifers community. 
Gamal M. El-Shabrawy et al.

Sites study:

\section{MATERIALS AND METHODS}

Rayahs are the main channels of fresh water from Damietta and Rosetta branches, which are vital for irrigation, navigation, fishing and other domestic uses in Egypt. Two rayahs were investigated in this study;

1- El-Rayah El-Towfiky which starts from the Damietta branch at el-Kanater station and extends into the middle and the east of Delta heading north parallel to the Damietta branch until Mansoura city at station (T5) and then heading East ward within Dakahlia governorate even Manzalah city. This rayah extends with average length of 180-200 Km from El-Kanater and with average width $40-50 \mathrm{~m}$ and its average depth 2-3 $\mathrm{m}$. this rayah characterized by existence of many water plants and electricity stations on its beaches which include large water stations such as: Banha station and small water stations which heavily scattered on both sides of Rayah. This Rayah branched at the Mansoura city into sub-main branches: the first one: extending north to Damietta city, it is characterized by a lack of water and lack of breadth (little width); almost water disappears in Faraskour city. So the water samples are not collected from this branch. The second: run east to Dekerness, El-Gamalia and El-Manzalah. This branch ends into Manzalah Lake previously but now it doesn't reach it. Also this branch is characterized with abundantly water as compared with the first branch. Seven samples were collected from this branch.

2- El-Rayah El-Nassery starts from the Rosetta branch at El-Kanater and runs in the West of Delta where it is heading northwest in the direction of Nubaria canal, and meet it at Kanater Pauline (Kom Hamada), then heading to the northwest even Mediterranean Sea breaking Mariot Lake. The length of This Rayah could be up to $200 \mathrm{Km}$ from El-Kanater and with average width 40-50 m and its average depth 2-3 m. This rayah characterized by existence of many water plants and electricity stations on its beaches especially on El Nubaria canal. Eight samples were taken from this rayah.

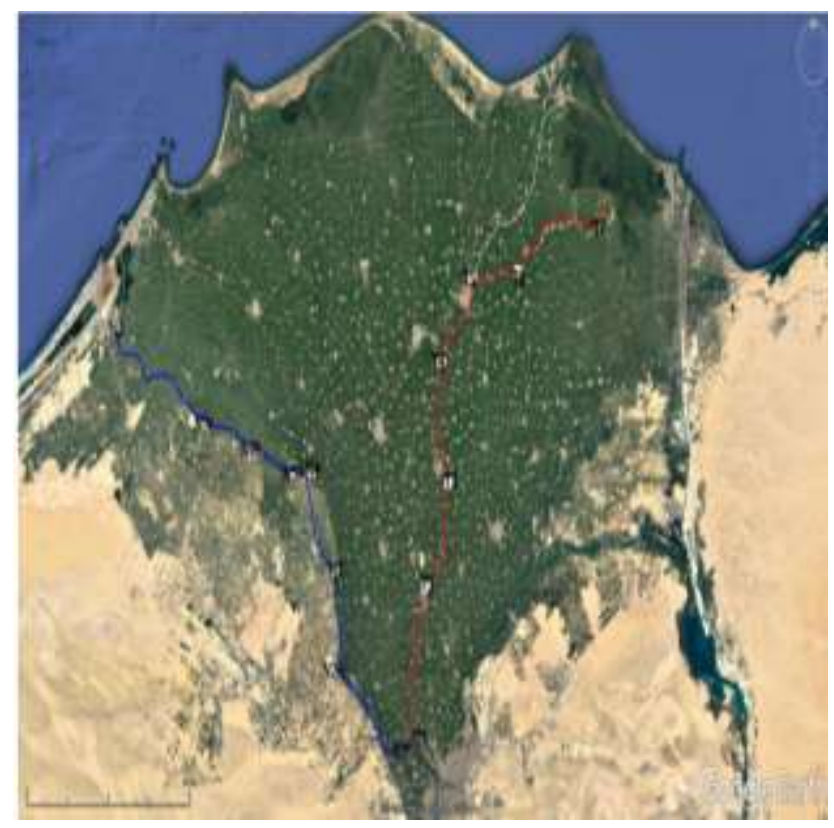

Fig (1): Map of El-Rayah El-Tawfeky and El-Rayah El-Nasery demonstrating the collected Stations. 


\section{Comparative analysis of rotifer community in two Rayahs of River Nile, Egypt}

\section{Sampling:}

Water samples were conducted seasonally throughout 2014. All samples took place from surface water from each station. Prior to sampling, the $\mathrm{pH}$, dissolved oxygen, water temperatures and electrical conductivity were measured in situ using portable meters. Thirty liters of each water sample were filtered through a zooplankton net of $55 \mu \mathrm{m}$ mesh diameter. Samples were subsequently taken back to the laboratory and preserved in $4 \%$ formaldehyde. Rose Bengal was added to facilitate separation of organisms from the suspended matter. Sub samples of $1 \mathrm{ml}$ were drawn from each sample (after careful mixing) using a wide-pipette (McCallum, 1979). The contents of such pipette were let to flow freely into $1 \mathrm{ml}$ SedgwickRafter cell. Three successive sub samples were examined under a binocular compound microscope at 10x magnification. Identification of various rotifer taxa were based on the works of Edmondson (1959) and Foissner and Berger (1996).

\section{Data analysis:}

The diversity indices of rotifer species were seasonally calculated as Species Richness, Shannon-Weaver Diversity Index and Index of Evenness by using Primer 5 (2001); the indices were calculated at individual species level. Principal component analysis (PCA) between different rotifer main species and environmental variables at the study area was performed using XLSTAT, 2014.

\section{Physico- chemical analysis:}

\section{RESULTS AND DISCUSSION}

The physico-chemicals parameter of El-Rayah El- Tawfeky and El- Nasery were determined seasonally and nearly similar in variation as shown in Table (1). The values of $\mathrm{pH}$ at the studied area were in the alkaline side and recorded the maximum value in summer and the minimum reading in winter in El-Rayah El-Tawfeky and El-Nasery with annual average 8.27 and 8.34, respectively. Alkaline pH helps flourishment and growth of rotifer (Sharma $\boldsymbol{e t}$ al., 2015). This tendency to the alkaline side may be due to the increased photosynthetic activity of planktonic algae, or to the chemicals nature of water (Fathi and Kobbia, 2000). It showed positive correlation with temperature in El-Rayah El-Tawfeky and El-Nasery ( $\mathrm{r}=$ $0.663 ; 0.607$, respectively), and showed negative correlation with dissolved oxygen in ElRayah El-Nasery ( $\mathrm{r}=-0.415)$.

Temperature is considered the main factor affecting directly or indirectly not only on population density, species composition and richness of rotifers in freshwaters, but also on their growth activity, activation of reproduction processes and susceptibility to diseases (Shayestehfar et al., 2008 ; Kaya et al., 2010 ; Moustafa et al., 2010). Water temperature has the same pattern of $\mathrm{pH}$, where it recorded the maximum value in summer and decreased to minimum reading in winter in El-Rayah El-Tawfeky and El-Nasery with annual average $23.89^{\circ} \mathrm{C}$ and $24.75^{\circ} \mathrm{C}$, respectively. It showed negative correlation with Dissolved Oxygen (DO) in El-Rayah El-Tawfeky ( $\mathrm{r}=-0.388)$ and Ec in El-Rayah El-Nasery $(\mathrm{r}=-0.619)$.

The annual average of electrical conductivity (EC) was $431.46 \mu \mathrm{S} / \mathrm{cm}$ in El-Rayah ElTawfeky and $417.41 \mu \mathrm{S} / \mathrm{cm}$ in El-Rayah El-Nasery. The maximum value of EC was recorded in autumn in El-Tawfeky and in winter in El-Nasery and decreased to minimum value in summer season in two rayahs. EC values are negatively correlated with DO in El-rayah ElTawfeky. The highest value of electrical conductivity could be due to the high pollution levels in water, resulted from the high nutrient loads of wastewater (Kobbia et al., 1995; Fathi and Al-Kahtani, 2009). The lowest reading of EC during summer in Rosetta branch of River Nile may be attributed to the increase of water level during flood period and uptake of dissolved salts by phytoplankton (Saad et al., 2011) 
Gamal M. El-Shabrawy et al.

The presence of oxygen in water is an important factor for most aquatic plants and animals to survive (Stahl and Ramadan, 2008), and plays an important role in the occurrence and abundance of rotifer species, (Hoffman, 1977). The mean dissolved oxygen value recorded was $7.15 \mathrm{mg} / \mathrm{l}$ in El-rayah El-Tawfeky and $7.63 \mathrm{mg} / \mathrm{l}$ in El-rayah El-Nasery. It increased to the maximum value in winter and recorded the minimum one in autumn. The highest of DO in winter may be due to the activities of wind action that permits high solubility of oxygen in atmosphere and the transfer of more oxygen across the air-water interface (Ibrahim et al., 2008 ; Mahmoud et al., 2008).

Table (1): Range of variations in main physical and chemical parameters in main River Nile rayahs measured during the investigated period.

\begin{tabular}{|c|c|c|c|c|c|c|c|c|c|c|}
\hline & \multicolumn{4}{|c|}{ El-Rayah El-Tawteky } & & \multicolumn{4}{|c|}{ El-Rayah EH-Nasery } & \\
\hline & Spring & Summer & Autumn & Winter & Annual Average & Spring & Summer & Autumn & Winter & Annual Average \\
\hline $\mathrm{pH}$ & $\left(\begin{array}{l}(7.07 \cdot 0.47) \\
8.21\end{array}\right.$ & $\begin{array}{c}(0.39 .8 .58) \\
8.19\end{array}$ & $\begin{array}{c}(8.29 .0 .41) \\
8.25\end{array}$ & $\begin{array}{c}(7.96 .8 .12) \\
8.09\end{array}$ & 8.27 & $\begin{array}{c}\text { (10.15.8.46) } \\
8.91\end{array}$ & $\begin{array}{c}(10.44 .0 .67) \\
8.50\end{array}$ & $\begin{array}{c}(8.11 .8 .81) \\
8.39\end{array}$ & $\left(\begin{array}{c}(1.02-1.26) \\
8.15\end{array}\right.$ & 8.34 \\
\hline Temp OC & $\begin{array}{c}(26.3 .22 .2) \\
21.1\end{array}$ & $\begin{array}{c}(24.5 \cdot 31.5) \\
32.63\end{array}$ & $\begin{array}{c}(21.6-22.7) \\
22.56\end{array}$ & $\begin{array}{c}(142-23] \\
15.24\end{array}$ & 23.89 & $\begin{array}{c}(25.9-20.3) \\
27.03\end{array}$ & $\begin{array}{c}(2.1-33) \\
31.03\end{array}$ & $\begin{array}{c}{[22.25 .11} \\
23.20\end{array}$ & $\begin{array}{c}(15-19.8) \\
17.76\end{array}$ & 24.75 \\
\hline EC $\mu 5 \mathrm{~cm}$ & $\begin{array}{c}\mid 353729 \\
416.29\end{array}$ & $\begin{array}{c}\text { (915 } 785) \\
41314\end{array}$ & $\begin{array}{c}4018101 \\
475.29\end{array}$ & $\begin{array}{c}\text { (398 181) } \\
421.14\end{array}$ & 431.45 & $\begin{array}{c}|315510| \\
59738\end{array}$ & $\begin{array}{c}\text { C57 } 365 \mid \\
15938\end{array}$ & $\begin{array}{c}\text { HCA 6021 } \\
44225\end{array}$ & $\begin{array}{c}(410710 \mathrm{k} \\
675.13\end{array}$ & 417.41 \\
\hline DO $\mathrm{mg}$ & $\int_{\text {f.96 }}^{(4.39-7.85)}$ & $\begin{array}{c}(4.83 .7 .62) \\
674\end{array}$ & $\begin{array}{c}(5.30 .7 .57) \\
6.5 \pi\end{array}$ & $\begin{array}{c}(5.02 .10 .19) \\
n .40\end{array}$ & 7.16 & $\begin{array}{c}(7.42 .8 .4) \\
7.03\end{array}$ & $\begin{array}{c}(6.4-10.85) \\
7.34\end{array}$ & $\begin{array}{c}(5.60-8.12) \\
A .98\end{array}$ & $\begin{array}{c}(16.63 \cdot .8 .12) \\
8.75\end{array}$ & 7.63 \\
\hline
\end{tabular}

\section{Rotifer species Composition and Distribution:}

A total of 40 species of rotifers were recorded, these species were listed in Table (2). 37 species were appeared in both rayahs. The highest number of species was observed in summer. 25 species at station 2 in El-Rayah El-Tawfeky and 27 species at station 3 in ElRayah El-Nasery, consequently the highest species richness of 1.85 and 1.99, respectively was recorded. The lowest number of species and richness was recorded in winter season, 6 species and 0.48 at station 5 in El-Rayah El-Tawfeky and 10 species and 0.83 at station 2 in El-Rayah El-Nasery, (Fig. 2A\&C and Fig. 3A\&C). Higher diversity of rotifers in summer might be attributed to enhanced rate of population growth at higher temperatures (Galkovskaya, 1987), and the production of new species in summer and inflow of large amount of river water into the flood plain water during summer, which brought different types of riverine species into the floodplain (Segers, 2008). This result agrees with the work of Saler and Sen (2002); Malik and Sulehria (2003, 2004) and Schöll and Kiss (2008).

The annual density of rotifers in El-Rayah El-Nasery (5442000 Ind. $/ \mathrm{m}^{3}$ ) during the study was higher than that in El-Rayah El-Tawfeky (3680000 Ind. $\left./ \mathrm{m}^{3}\right)$. Rotifer density was more abundant in spring season and recorded the minimum value in winter season in both rayahs. Stations 2 and 1 attained the greatest value of rotifer density (2352000 Ind. $/ \mathrm{m}^{3}$ and 2256000 Ind. $/ \mathrm{m}^{3}$ ) in El-Rayah El-Tawfeky and El-Rayah El-Nasery. Sharply decreased to the minimum reading of rotifer density at station 5 and 3 (36000 Ind. $/ \mathrm{m}^{3}$ and $42000 \mathrm{Ind} . / \mathrm{m}^{3}$ ) in El-Rayah El-Tawfeky and El-Rayah El-Nasery, respectively (Figs. 2B \& 3B). The dominance of rotifers in spring may be attributed to the favorable conditions as suitable temperature, stable water condition and abundance of food. Abdel Aziz, (2005) and Cooke et al. (2005) found that the highest rotifer's crop during spring may be due to the presence of dissolved organic matter. This result agrees with (Amer, 2007 ; Zakaria, 2007; Khalifa, 2014; Khalifa and Bendary, 2016).

Diversity index was abundant in summer season and showed remarkable decreased in autumn in both rayahs. On the contrary, evenness was higher in summer in El-Rayah El- 


\section{Comparative analysis of rotifer community in two Rayahs of River Nile, Egypt}

Tawfeky. While in El-Rayah El-Nasery, it was slightly increased in winter except station 4 \& 6 (Fig. 2D \& E and Fig. 3 D\&E).

In this work, Prolides $s p$ was the most dominant rotifer species. It contributed about $28.4 \%$ and $28.9 \%$ of the total rotifer density in El-Rayah El-Tawfeky and El-Rayah ElNasery, respectively. It attained its highest population density in spring in El-Rayah ElTawfeky and in autumn in El-Rayah El-Nasery. In winter season, Prolides sp showed the minimum value in two rayahs. El-Shabrawy and Dumont (2003), Saad et al. (2013) and ElShabrawy and Germoush (2014) found that Prolides sp was one of the dominant rotifer species in many freshwater bodies in Egypt.

Genus keratella was the second dominant rotiferan genus which represented by $K$. cochlearis and $k$. tropica. Keratella cochlearis contributed about $16.9 \%$ in El-Rayah ElTawfeky and $21.6 \%$ in El-Rayah El-Nasery of total rotifer density. It recorded the highest density in spring and the least density count in autumn season. Keratella tropica formed 13\% and $12 \%$ of total rotifer density in El-Rayah El-Tawfeky and El-Rayah El-Nasery. The maximum density of Keratella tropica showed in spring in El-Rayah El-Tawfeky and in autumn in El-Rayah El-Nasery. It sharply decreased to the lowest reading in winter season in two rayahs. Pejler and Bērziņš (1989) and Koste (1978) believed that, Keratella cochlearis is one of the most common representatives of the family Brachionidae and is known to inhabit a diverse range of waters. The dominant result of Keratella cochlearis agreed with ( Pace et al., 1992; Van Dijk and Van Zanten, 1995; May and Bass, 1998; Burger et al., 2002; Khalifa,2014 and Khalifa and Bendary, 2016).

Trichocerca represented by four species T.Pusilla, T.olngata, T.cylindrica and T.porcellus. Among which T. pusilla dominated and detected about $10.4 \%$ of total rotifer in El-Rayah El-Tawfeky and $7.3 \%$ in El-Rayah El-Nasery. It flourished in autumn and decreased to the lowest density in winter season.

Brachionus was the most taxon-rich genus being represented by eight species; however their densities were very low throughout the study period, the high richness of Brachionidae indicates eutrophic conditions according to Mageed, 2008; Claps et al, 2011 and Perbiche-Neves, 2013. Kumari et al. (2008) described Keratella sp. and Brachionus sp. as pollution indicator species. B. caudatus, and B. calyciflorus dominated and detected in all seasons. B. calyciflorus contributed about $4.5 \%$ and 5.2\% in El-Rayah El-Tawfeky and ElRayah El-Nasery respectively. It peaked in autumn and decreased in winter.

The population density of $B$. caudatus increased in spring and decreased in winter and recorded about $4.7 \%$ and $2.5 \%$ El-Rayah El-Tawfeky and El-Rayah El-Nasery respectively. El-Bassat (1995) referred that high existence of these genus at Delta Barrage was attributed to there ability to tolerate pollution.

The population density of Polyarthra vulgaris increased in spring in El-Rayah ElTawfeky and its crop decreased in winter but it constituted $6.1 \%$ of total rotifers. The species flourish in autumn season and gradually decreased to the lowest density in winter and attained to form about $6.5 \%$ in El-Rayah El-Nasery. This result agreed with Khalifa (2000 \& 2014), El-Bassat (2002) and George (2012) whereas they recorded the dominance of this species in late spring and autumn. And attributed the high abundance to high eutrophication level and reported this species as good indicators of eutrophication. On the contrary, Polyarthra spp. has been recorded as indicator of clean water with low temperature (Bahura et al. 1993).

Philodina roseola flourished in spring to the maximum value of density and sharply decreased in winter season. It contributed about $3.4 \%$ of total rotifer density in El-Rayah ElTawfeky and $2.9 \%$ in El-Rayah El-Nasery. Khalifa (2000) believed that, Philodina roseola appeared more tolerant to the industrial waste in River Nile and might be used as indicators of industrial waste pollution. 
Gamal M. El-Shabrawy et al.

\section{Principal Component Analysis:}

Principal Component Analysis (PCA) considering physical and chemical data beside the densities of main Rotifer species for El-Rayah El-Tawfeky is shown in Figure (4). The first ax of the PCA explained $41.81 \%$ of the variance and was positively correlated with $K$. cochlearis, K. tropica, B. caudatus, B. calyciflorus, Proalides sp, T. pusilla and P. vulgaris. Axes 2 explained $17.01 \%$ of the variance; it was positively correlated with physico-chemical variables conductivity and dissolved oxygen.

An ax 1 of the PCA for El-Rayah El-Nasery explained $42.14 \%$ of the variance and was positively correlated with Proalides sp, $K$. tropica, T. pusilla, B. calyciflorus and $P$. vulgaris. Axes 2 explained 19. 17\% of the variance; it was positively correlated with $K$. cochlearis and B. caudatus, (Fig: 5).

\section{Recomindation:}

The present study recommended

1- Using rotifer species as a bioindicators for water quality to provide early warning mechanisms of possible environmental damage.

2- The impacts of effluents can also be tested before their discharge into River Nile water.

3- Drainage wastewater should be treated using more advanced methods prior to discharge into River Nile and its branches.

Table (2): Rotifer species collected from main River Nile rayahs (Tawfeky and Nasery) during the investigated period.

\begin{tabular}{|l|c|c|l|c|c|}
\hline \multicolumn{1}{|c|}{ Rotifer species } & $\begin{array}{c}\text { El-rayah } \\
\text { El- } \\
\text { Tawfeky }\end{array}$ & $\begin{array}{c}\text { El-rayah } \\
\text { El- } \\
\text { Nassery }\end{array}$ & \multicolumn{1}{|c|}{ Rotifer species } & $\begin{array}{c}\text { El-rayah } \\
\text { El- } \\
\text { Tawfeky }\end{array}$ & $\begin{array}{c}\text { El-rayah } \\
\text { El- } \\
\text { Nassery }\end{array}$ \\
\hline Anuraeopsis fissa & + & + & L.luna & + & + \\
Asplanchna priodonta & + & + & L. sp & - & + \\
Brachionus angularis & + & + & L.ungulata & + & - \\
B. budapestinensis & + & + & Lepadella patella & + & + \\
B. calyciflorus & + & + & Polyarthra vulgaris & + & + \\
B. caudatus & + & + & Proalides sp & + & + \\
B. falcatus & + & + & Philodina roseola & + & + \\
B. plicatilis & + & + & Rotaria sp & + & + \\
B. quadridentatus & + & + & Scaridium & + & + \\
B. patulus & + & + & longicaudum & + & - \\
Cephalodella gibba & + & + & Synchaeta pectinata & & \\
Collotheca pelagica & + & + & Testudinella patina & + & + \\
Colurella adriatica & + & + & Trichocerca & + & + \\
Conochilus unicornis & + & + & elongata & + & + \\
Epiphanes macrourus & + & + & T. cylindrical & + & + \\
Euchlanis dilatata & + & + & T. pusilla & & \\
Filinia longisetea & + & + & T. porcellus & + & + \\
Hexarthra mira & + & + & Trichotria tetractis & + & + \\
Keratella cochlearis & + & + & & & \\
K. tropica & + & + & & & \\
Lecane aculeata & + & + & & & \\
L. bulla & + & + & & & \\
L. leontina & + & + & & \\
L. closterocerca & + & + & & \\
& & & & \\
\hline
\end{tabular}


Comparative analysis of rotifer community in two Rayahs of River Nile, Egypt
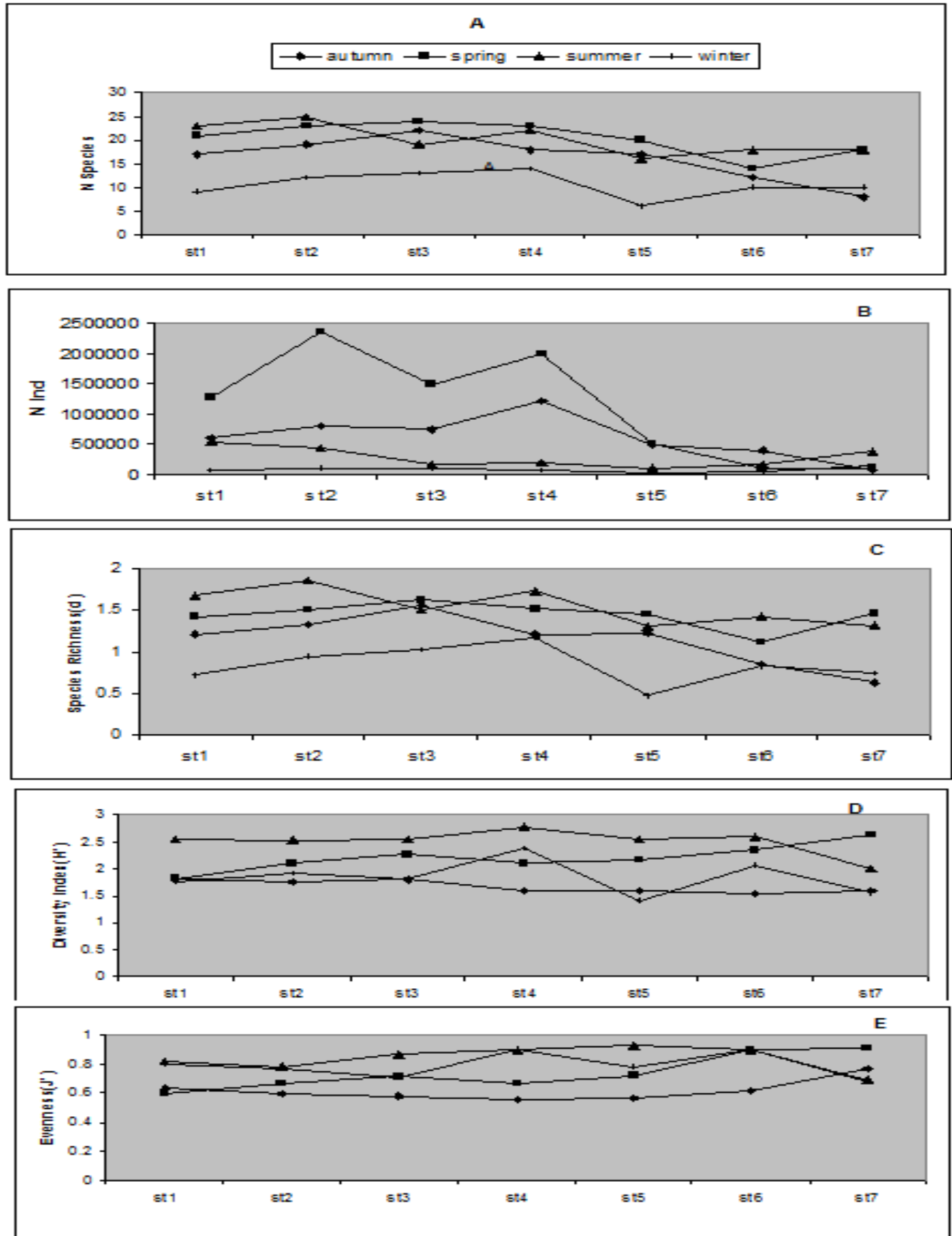

Fig. 2: A. Species number, B: Population density, C: Species richness, D: diversity index and E: Evenness of rotifers at El-Rayah El-Taweky during 2014. 
Gamal M. El-Shabrawy et al.

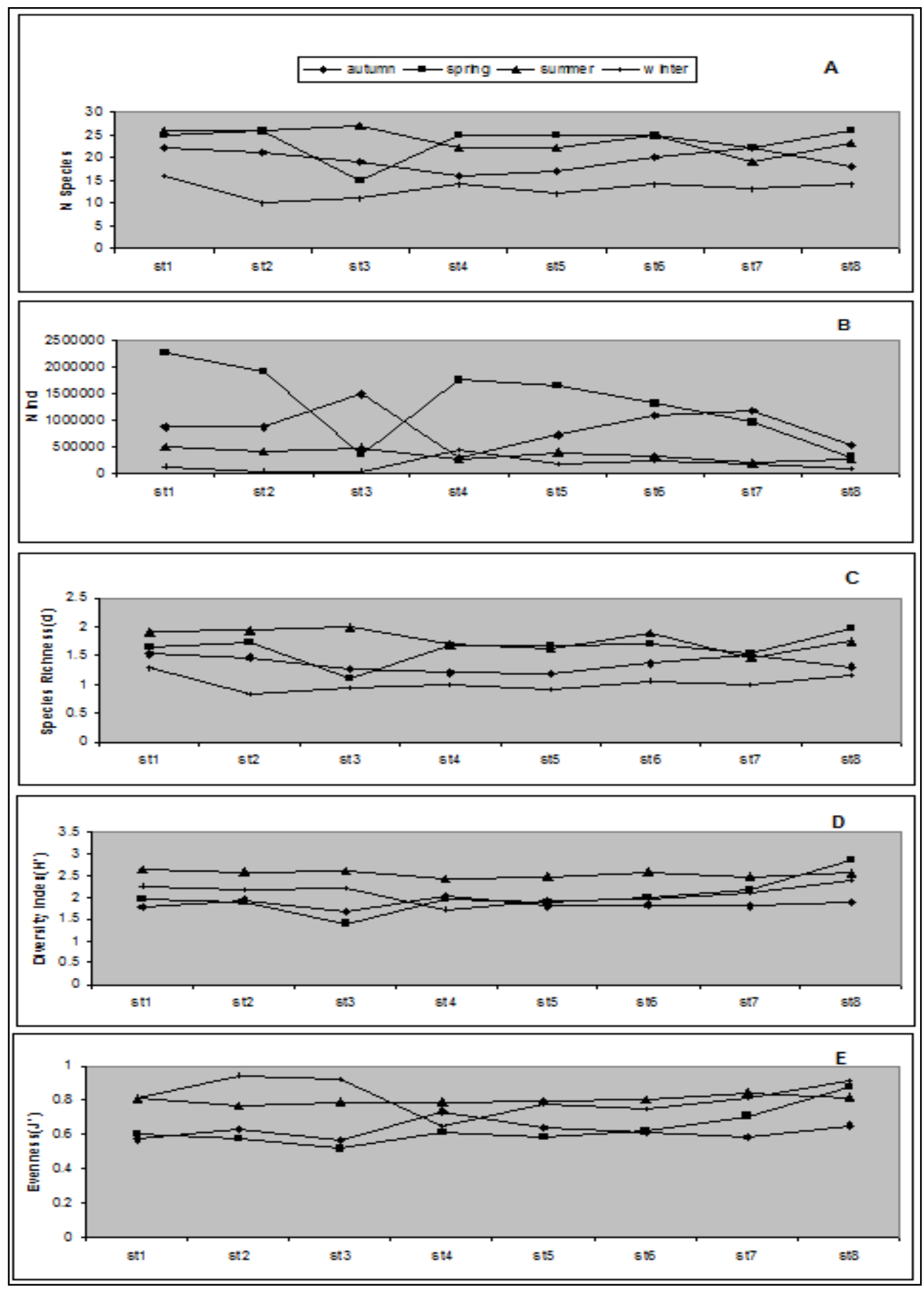

Fig. 3: A. Species number, B: Population density, C: Species richness, D: diversity index and E: Evenness of rotifers at El-Rayah El-Nasery during 2014. 
Comparative analysis of rotifer community in two Rayahs of River Nile, Egypt

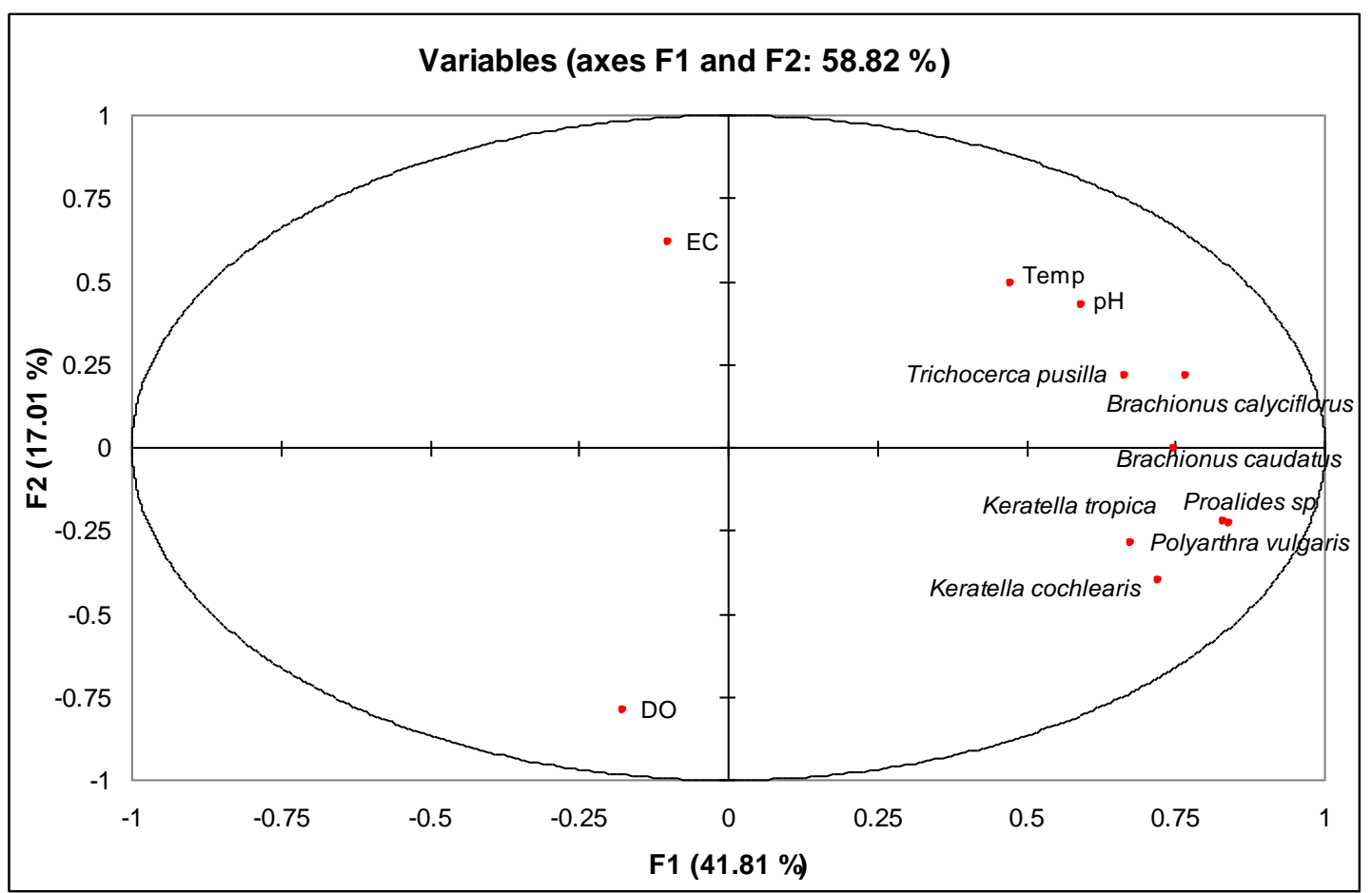

Fig. 4: Principal Component Analysis (PCA) of Physico-chemical Variables and the Main Rotifer Species in El-Rayah El-Tawfeky. Temp. : Temperature, EC: Electrical Conductivity and DO: Dissolved Oxygen.

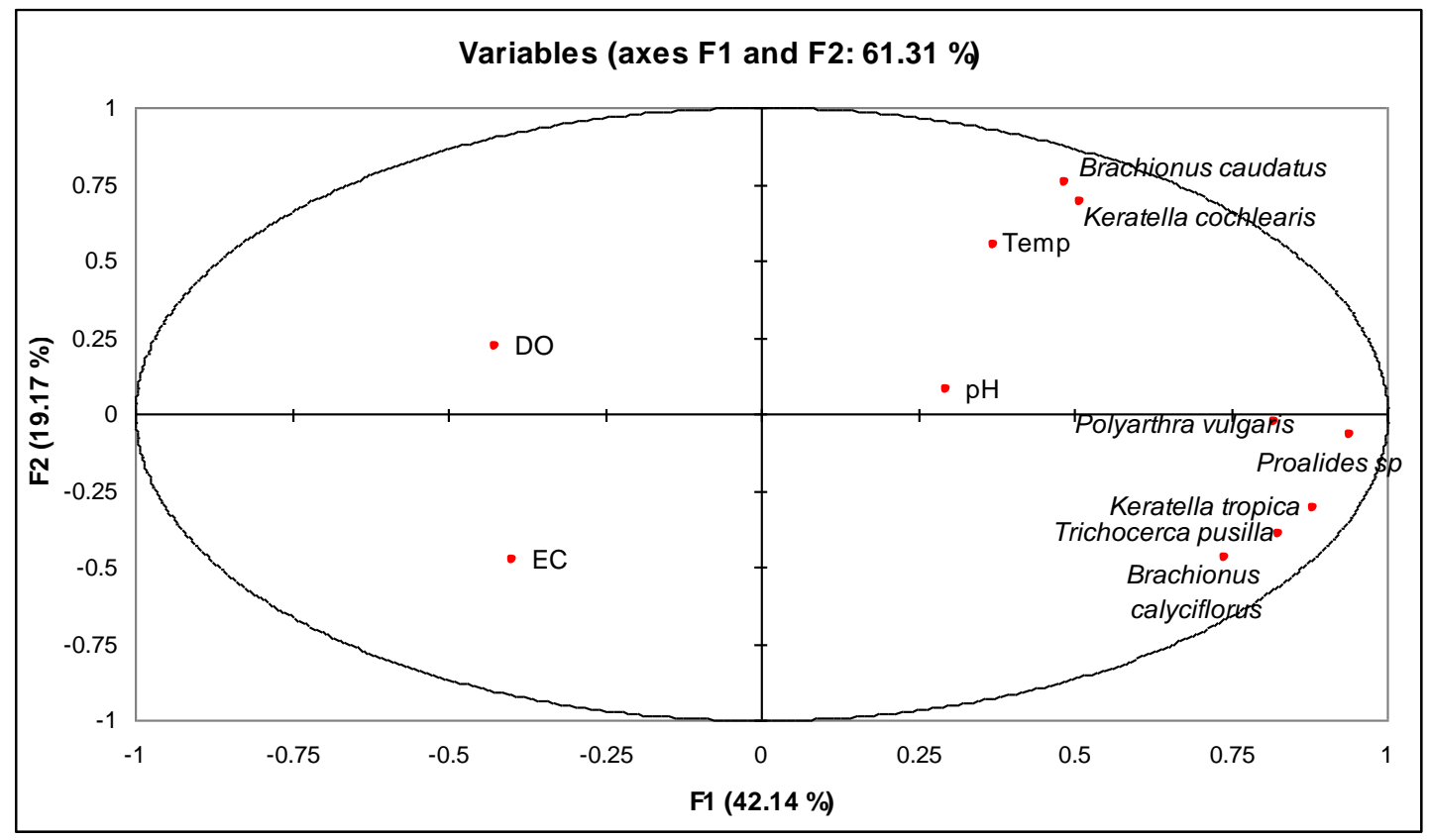

Fig. 5: Principal Component Analysis (PCA) of Physico-chemical Variables and the Main Rotifer Species in El-Rayah El-Nasery. Temp. : Temperature, EC: Electrical Conductivity and DO: Dissolved Oxygen. 
Gamal M. El-Shabrawy et al.

\section{REFERENCES}

Abd El-Mageed, A. A. (2001). Zooplankton composition of some industrial polluted areas in the River Nile ecosystem. Egypt. J. Aquat. Biol. and Fish, 5 (2): 1-20.

Abdel Aziz, N.E. (2005). Short-term variations of zooplankton community in the west Naubaria Canal, Alexandria, Egypt. Egypt. J. Aquat. Res., 31: 119-131.

Abo-Taleb, H.A.H. (2009). Dynamics of zooplankton community in the connection between the Mediterranean Sea and the River Nile at Rosetta branch, Egypt. B.Sc.Fac. of Sci.Al-Azhar University.181pp.

Aboul-Ezz, S.M.; Salem, S.A.; Samaan, A.A.; Latif, A.F.A. and Soliman, A.A. (1996). Distribution of rotifers in the Rosetta Nile branch (Egypt). J.Egypt.Ger. Soc. Zool., 20(D): 85-123.

Allan, J.D. (1976). Life history patterns in zooplankton. Am. Nat., 10: 165-180.

Amer, A.S. (2007). Effect of different types of pollutants on Bacteria-Zooplankton interaction in the Nile water. Ph.D.Thesis, Fac. of Science, Zoology Dept., Girls College, Ain Shams University. 227pp.

Andrew,T.E. and Fizsimous, A.G.(1992). Seasonality, population dynamics and production of planktonic Rotifers in Lough Neagh, Northern Ireland. Hydrobiologia, 246: 147164.

Bahura, C.K.; Bahura, P. and Saxena, M.M. (1993). Zooplankton community of Shivbari temple tank, Bikaner. J. Ecol., 5: 5-8.

Bedair, S.M. (2006). Environmental studies on zooplankton and phytoplankton in some polluted areas of the River Nile and their relation with feeding habit of fish. Ph.D.Thesis, Fac. of Sci. Zagazig University.

Brooks, J.L. and Dodson, S.I. (1965). Predation, body size and composition of plankton. Science, 150: 28-35.

Burger, D.F.; Hogg, I.D. and Green, J.D. (2002). Distribution and abundance of zooplankton in the Waikato River, New Zealand. Hydrobiologia, 479: 31-38.

Claps, M.C.; Gabellone, N.A. and Benítez, H.H. (2011). Seasonal changes in the vertical distribution of rotifers in a eutrophic shallow lake with contrasting states of clear and turbid water. Zoological Studies, 50(4): 454-465.

Cooke, S.L; Williamson, C.E.; Hargreaves, B.R. and Morris, D.B. (2005). Beneficial and detrimental interactive effects of dissolved organic matter and ultraviolet radiation on zooplankton in a transparent lake. Hydrobiol., 568 (1): 15-28.

Dumont, J.H. (2007). Rotifers, the jelly plankton of freshwater. Hydrobiologia, 593: 59-66.

Edmondson,W.T. (1959). Reproductive rate of planktonic Rotifers as related to food and temperature in nature. Ecological Monographs, 35(1): 66-1111.

El-Bassat, R.A. (1995). Ecological studies of zooplankton on the River Nile. M.Sc. Thesis, Fac. of Sci., Suez canal Univ., 199 pp.

El-Bassat, R.A. (2002). Ecological studies on zooplankton communities with particular reference to free living protozoans at River Nile - Damietta Branch. Ph.D. Thesis, Women College For Arts, Education \& Science, Ain Shams Univ.

El-Feky, F.A. and Khalifa, N.S. (2014). Distribution and abundance of Rotifers in the River Nile, Egypt. World J. Fish and Mar. Sci., 6(6): 557-563.

El-Shabrawy, G.M. (2000). Seasonal and spatial variation in zooplankton structure in Lake Nasser. Pelagic area of the main channel, Egypt. Egypt. J. Aquat. Biol. and Fish., 4: 61-84. 


\section{Comparative analysis of rotifer community in two Rayahs of River Nile, Egypt}

El-Shabrawy, G.M. and Dumont, H.J. (2003). Spatial and seasonal variation of the zooplankton in the coastal zone and main khors of Lake Nasser, Egypt. Hydrobiologia 49: 119-132.

El-Shabrawy, G.M. and Germoush, M.O.A (2014). Seasonal changes and abundance of rotifers in a shallow Manzalah Lake, Egypt. Ecohhydrology \& Hydrobiology, 14:243252.

Emam,W. (2006). Preliminary study on the impact of water pollution in El-Rahawy drain dumping in Rosetta Nile branch on zooplankton and benthic invertebrates. M.Sc. Thesis, Zoology Dept., Faculty of Science, Ain Shams University.

Fathi, A.A. and Al-Kahtani, M.A. (2009). Water Quality and Planktonic Communities in AlKhadoud Spring, Al-Hassa, Saudi Arabia. Am. J. Environ. Sci., 5 (3): 434-443.

Fathi, A.A. and Kobbia, I.A. (2000). Hydrobiological investigation of Abou-Median lake, ElMinia, Egypt. Bullten of Faculty of Science of Assiut University 29, 77-91.

Foissner,W. and Berger, H.(1996). A user-friendly guide to the ciliates (Protozoa, Cilliophora) commonly used by hydro biologists as bioindicators in rivers, lakes and waste waters, with notes on their ecology. Freshwater Biol., 35(2): 375-482.

Galal, M. and Gaber, N. (2002). Population densities of protozooplankton and their response to certain factors in the River Nile in El-Menofeyia province, Egypt. Ger. Soc.Zool. 38(D): 1-14.

Galkovskaya, G.A. (1987). Planktonic rotifers and temperature. Hydrobiologia, 147:307-317.

Gannon, J.E. and Stemberger, R.S. (1978). Zooplankton especially crustaceans and rotifers as indicators of water quality. Transactions of the Am. Microscopical Soc., 971: 16-35.

George, M.N. (2012). Ecological studies on aquatic invertebrates of Ismalia Canal, Egypt. M.Sc. Thesis, Faculty of Science, Ain Shams Univ.

Herzig, A. (1983). Comparative studies on the relationship between temperature and duration of embryonic development of rotifers. Hydrobiologia, 104:237-246.

Hoffman, W. (1977). The influence of a biotic environmental factors on population dynamics in planktonic rotifers. Archiv für Hydrobiologie-Beiheft Ergebnisse der Limnologie, 8: 77-83.

Ibrahim, S.M.; Shallof, K.A. and Salama, H.M. (2008). Effect of environmental conditions of Abu-Zabal Lake on some Biological, Histological and Quality Aspects of Fish, Global Veterinaria, 2(5): 257-270.

Kaya, M.; Segers, D.F.H. and Altindağ, A. (2010). Temperature and salinity as interacting drivers of species richness of planktonic rotifers in Turkish continental waters. J. Limnol., 69(2): 297-304.

Khalifa, N.S. (2000). Study on the impact of industrial wastes at Helwan on River Nile zooplankton. Ph. D. Thesis, Faculty of of Science, Cairo Univ.

Khalifa, N. S. (2014): Population dynamics of rotifera in Ismailia Canal,Egypt. Journal of Biodiversity and Environmental Sciences, Vol: 4(2):58-67.

Khalifa, N.S. and Bendary, R.E. (2016): Composition and biodiversity of zooplankton and macrobenthic populations in El-Rayah El-Menoufy, Egypt. Int. J. Appl. Environ. Sci., 11(2):683-700.

Kobbia, I.M.; Metwali, R.M. and El-Adel, H.M. (1995). Influence of water effluents of soap and oil factory at Benha on Nile phytoplankton communities. Egypt. J. Botany, 35: 45-57.

Koste, W. (1978). Rotatoria. Die Rädertiere Mitteleuropas. Gebrüder Borntraeger, 1(2): Berlin, 673 pp +234 pl.

Kumari, P.; Dhadse, S.; Chaudhari, P. R. and Wate, S.R. (2008). A biomonitoring of plankton to assess quality of water in the lakes of Nagpur city. In: Sengupta M. and Dalwani R. (Eds). Proc. of Taal. The 12 ${ }^{\text {th }}$ World Lake Conference, 160-164. 


\section{Gamal M. El-Shabrawy et al.}

Mageed, A. (2008). Distribution and long-term historical changes of zooplankton assemblages in Lake Manzala (South Mediterranean Sea, Egypt). Egypt. J. Aquat. Res., 33(1): 183-192.

Mahmoud, S.A.; Tayel, S.I. and Yacoub, A.M., (2008). Histopathological changes in kidneys of the fish Tilapia zillii and Clarias gariepinus under the effect of several pollutants along the River Nile. J. Egypt. German Soc. Zool., 56(C): 219-246.

Malik, M.A.. and Sulehria, A.Q.K. (2003). Seasonal variation, density and diversity of planktonic rotifers in Jallo lake. Biologia (Pakistan), 49: 77-88.

Malik, M. A. and Sulehria, A.Q.K. (2004). Seasonal variation, density and diversity of planktonic rotifers in the River Ravi. Biologia (Pakistan), 50: 5-17

May, L. and Bass, J.A.B. (1998). A study of rotifers in the River Thames, England, AprilOctober, 1996. Hydrobiologia, 387(388): 251-257..

McCallum, I.D. (1979). A simple method of taking subsample of zooplankton. N.Z.J.Mar. Freshwater Res., 13:559-560.

Mola, H.R.A. (2011). Seasonal and spatial distribution of Brachionus (Palla, 1966; Eutotatoria: Monogonanta: Brachionidae), a bioindicator of eutrophication in lake ElManzalah, Egypt. Biology and Medicine, 3 (2): 60-69.

Moustafa, M.M.; Ali, M.H H.; Abdel-Satar, A.M.; Mohamed, T.Y. and Madbouly, S.M. (2010). Water quality assessment of Rosetta and Damietta branches, River Nile, Egypt. Afric. J. Biol. Sci., 6(2): 127-142.

Pace, M.L.; Findlay, S.E.G. and Lints, D. (1992). Zooplankton in advective environments: The Hudson River community and a comparative analysis. Can. J. Fish. and Aquatic Sci., 49: 1060-1069.

Pejler, B. and Bērziņš, B. (1989). On chice of substrate and habitat in brachionid rotifers. Hydrobiologia, 186(187): 137-144.

Perbiche-Neves, G.; Fileto, C.; Laçoportinho, J.; Troguer, A. and Serafim-Júnior, M. (2013). Relations among planktonic rotifers, cyclopoid copepods, and water quality in two Brazilian reservoirs. Latin Am. J. Aquat. Res., 41 (1): 138-149.

Saad, A.A.; Emam, W.M.; El-Shabrawy, G. M and Gowedar, F. M. (2013). Sewage pollution and zooplankton on assemblage along the Rosetta branch at El-Rahawy area, Egypt. Int. J. Environ. Sci. and Engineering, 4: 29-45.

Saad, S.M.M.; El-Deeb, A.E.; Tayel, S.I. and Ahmed N.A.M. (2011). Haematological and histopathological studies on Claris gariepinus in relation to water quality along Rossetta branch, River Nile, Egypt. Egypt. J. Exp. Biol. (Zool.), 7(2), 223-233.

Saler, S. and Sen, D. (2002). Seasonal variation of Rotifera fauna of Cip Dam Lake (ElaziğTurkey). Pakistan J. biol. Sci., 5: 1274-1276.

Schöll, K. and KIss, A. (2008). Spatial and temporal distribution patterns of zooplankton assemblages (Rotifera, Cladocera, Copepoda) in the water bodies of the Gemenc floodplain (Duna-Dráva National Park, Hungary). Opusc. Zool. Budapest, 39: 65-76.

Segers, H. (2007). Annotated checklist of the rotifers (Phylum: Rotifera), with notes on nomenclature, taxonomy and distribution. Zootaxa, 1(564): 3-104.

Segres, H. (2008). Global diversity of rotifers (Rotifera) in freshwater. Hydrobiologia, 595: 49-59.

Sharma, K.K., Kour, S. and Antal, N. (2015). Diversity of zooplankton and macrobenthic invertebrates of two perennial ponds in Jammu Region. J. Glob. Biosc., 4(2): 13831393.

Shayestehfar, A.; Soleimani, M.; Mousavi, S.N. and Shirazi, F. (2008). Ecological study of rotifers from Kor river, Fars, Iran. J. Environ. Biol., 29(5): 715-720. 


\section{Comparative analysis of rotifer community in two Rayahs of River Nile, Egypt}

Stahl, R. and Ramadan, A.B. (2008). Environmental studies on water quality of the Ismailia Canal, Egypt. Scientific Report, Forschungszentrum Karlsruhe in der HelmholtzGemeinschaft Wissenschaftliche Berichte FZKA 7427.

Van Dijk, G.M. and Van Zanten, B. (1995). Seasonal changes in zooplankton abundance in the lower Rhine during 1987-1991. Hydrobiologia, 304:29-38.

Wallace, R.L. and Snell,T.W. (2010). Rotifera. Chapter 8. In: Ecology and classification of North American freshwater invertebrates (eds. Thorp, J.H. and A.P. Covich). Elsevier. xford. pp. 173-235.

Zakaria, H.Y. (2007). on the distribution of zooplankton assemblages in Abu Qir Bay, Alexandria, Egypt. Egypt. J. Aquat. Res., 33 (1): 238-256.

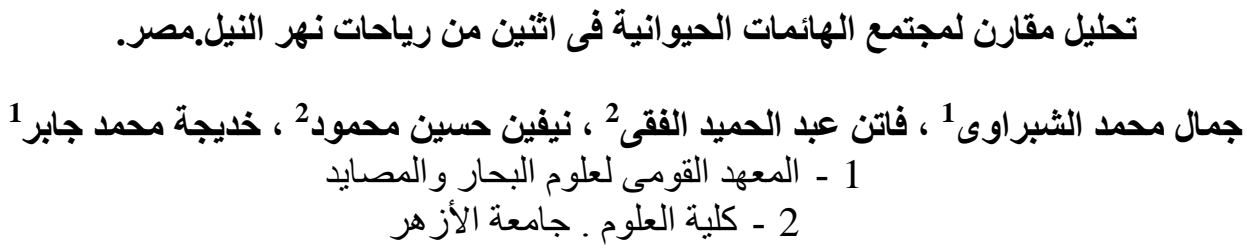

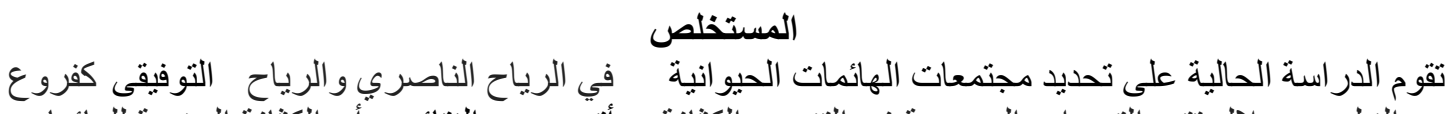

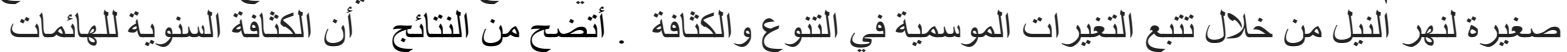

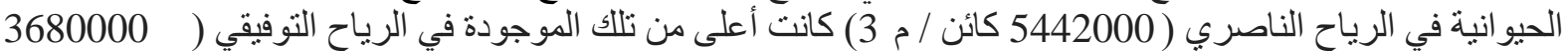

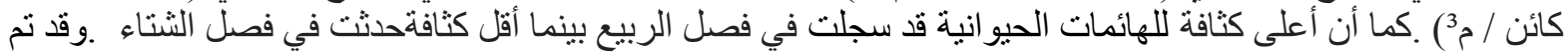

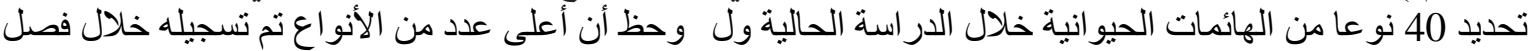
الصيف بينما أقل عدد كان فى فصل الثنات الثناء. 